\title{
FUNDING CELENGAN PADA BPRS SAFIR BENGKULU
}

\author{
Erma Putri Yani dan Yosy Arisandy \\ IAIN Bengkulu \\ E-mail: yosyarisandy@gmail.com
}

\begin{abstract}
Abstrak: The purpose of this study was to determine the effectiveness of the implementation of the funding piggy bank at PT. BPRS Safir Bengkulu and the factors that caused the stall traders to save in the funding piggy bank at PT. BPRS Safir Bengkulu. The research conducted is field research using qualitative methods. The data used in this study are Primary Data obtained through interviews with the Funding Division, Funding Officer, Costumer Service, General Division and Personnel, and Secondary Data obtained from books related to research problems. After the data is obtained then it is analyzed using qualitative descriptive method which is then analyzed deductively. The results of the study found that (1) the implementation of the funding piggy bank at PT. BPRS Safir Bengkulu. After a customer agreement with the BPRS Safir bank, the bank places the piggy bank with the customer, the customer saves the money in the box. After that the bank took the Warung savings, Hajj savings, and Qurban savings. And recorded according to the nominal savings. (2) factors that cause traders to save in the funding piggy bank at PT. BPRS Safir Bengkulu. Because of the friendly service. maintain customer trust, ease in saving, ease of obtaining information about products.
\end{abstract}

Kata Kunci: Funding, Celengan, Nasabah, Warung.

\section{PENDAHULUAN}

Bank Syariah adalah bank yang menjalankan kegiatan usahanya dengan didasarkan pada prisnsip syariah dan menurut jenisnya Bank Syariah terdiri dari BUS (Bank Umum Syariah), UUS (Unit Usaha Syariah) dan BPRS (Bank
Pembiayaan Rakyat Syariah), Bank Syariah merupakan Bank yang kegiatannya mengacu pada hukum Islam dan dalam kegiatannya tidak membebankan bunga maupun tidak membayar bunga kepada nasabah. Imbalan Bank syariah yang diterima maupun yang dibayarkan pada 
nasabah tergantung dari akad dan perjanjian yang dilakukan oleh pihak nasabah dan pihak Bank. Perjanjian (akad) yang terdapat di perbankan syariah harus tunduk pada syarat dan rukun akad sebagaimana diatur dalam syariat islam. ${ }^{1}$

BPRS adalah Bank syariah yang kegiatannya tidak memberikan jasa dalam lalu lintas pembayaran. Bentuk hukum BPRS perseroan terbatas. BPRS hanya boleh dimiliki oleh Warga Negara Indonesia (WNI) dan atau badan hukum Indonesia, Pemerintah daerah, atau kemitraan antara Warga Negara Indonesia (WNI) atau badan hukum Indonesia dengan pemerintah daerah. $^{2}$

Dalam UU No. 21 tahun 2008 pasal 1 ayat 2 menyatakan, Bankadalah badan usaha yang menghimpun dana dari masyarakat dalam bentuk Simpanan dan menyalurkannya kepada masyarakat dalam bentuk kredit dan/atau bentuk lainnya dalam rangka meningkatkan taraf hidup rakyat. Dari pasal tersebut dapat disimpulkan bahwa sistem hukum perbankan di Indonesia bank sebagai intermediary bagi masyarakat yang surplus dana dan masyarakat yang kekurangan dana.

\footnotetext{
${ }^{1}$ Muhammad Antonio Syafi'i, Bank Syariah dari Teori ke Praktik, Jakarta: Gema Insani Press. 2001), h. 2

2 AndriSoemitra, Bank dan lembaga Keuangan Syariah, (Kencana: Media Group. 2009), h. 61
}

Dikeluarkannya UU No 21 tahun 2008 harus di tanggapi positifbahwa ini merupakan salah satu bentuk perhatian pemerintah terhadap bank bagi hasil dari lebih populer dengan bank syariah. Menyadari hal itu prinsip bank syariah perlu di pertegas kembali, agar persepsi masyarakat yang memandang perbankan syariah sama dengan bank konvensional dapat dihilangkan. Karena hal itu akan menghambat proses sosialisasi yang terus di gulirkan, sehingga sikap masyarakat yang meliputi sikap terhadap sistem dan produk perbankan syariah menunjukan prospek yang menggembirakan terhadap sistem maupun produk perbankan syariah. Untuk itu, perlu di ciptakan daya inovasi baru untuk mendapatkan produk baru sebagai variasi dan produk yang telah ada dan akhirnya mampun menciptakan segmentasi pasar baru di Antara pasar yang telah ada.

BPRS Safir adalah Bank Perkreditan Rakyat Syariah Safir Provinsi Bengkulu terbaik kedua di Sumatera setelah salah satu BPRS di Bangka Belitung yang merupakan milik pemerintah setempat. Kita terbaik kedua dan terus akan meningkatkan pelayanan terbaik ke nasabah di Bengkulu," kata Komisaris BPRS Safir Bambang Sutrisno, ketika berkunjung ke Antara Biro Bengkulu. Bambang yang didampingi Dirut BPRS Safir Bengkulu Amir Mukadar menjelaskan, keberhasilan menempati 
peringkat kedua itu tak lepas dari sumber daya manusia yang ada. BPRS Safir ini juga memiliki produk yaitu produk funding celengan yang mana produk ini dilakukan pada warung-warung yang ada di kota bengkulu. Yang mana Produk fanding celengan ini menggunakan Akad Wadiah. ${ }^{3}$

Funding adalah kegiatan menghimpun dana dari nasabah atau calon nasabah yang berbentuk simpanan atau penyertaan modal guna penguatan modal kedalam.Salah satu karakteristik lembaga keuangan syari'ah adalah adanya mekanisme penitipan. Mekanisme lembaga keuangan syari'ah dengan menggunakan sistem titipan akan menjadi salah satu alternatif bagi masyarakat bisnis, karena mekanisme tersebut sangat berbeda dengan mekanisme ekonomi konvensional yang menggunakan instrumen bunga Kegiatan funding adalah mengumpulkan dana dari masyarakat kegiatan ini menawarkan berbagai cara dengan berbagai jenis simpanan. ${ }^{4}$

Celengan merupakan nama umum untuk kotak akumulasi atau penabungan koin. Umumnya, celengan digunakan oleh anak-anak. Celengan biasanya terbuat dari keramik atau porselen. Celengan bertujuan

\footnotetext{
${ }^{3}$ Muhamad Heykal, Nurul Huda, Lembaga Keuangan Islam Tinjauan Teoritis dan Praktis, (Jakarta: Kencana Prenada Media Group. 2010), h. 45

4 Ismail,.Perbankan Syariah, (Jakarta: Kencana Prenada Media Group. 2011), h. 6
}

untuk mengajarkan kepada anak untuk menabung. Pada celengan tradisional, uang dapat dengan mudah dimasukkan, namun jika ingin mengambil uangnya, celengan tersebut harus dipecahkan. Tapi celengan modern memiliki lubang karet pada bagian bawahnya, untuk memudahkan dalam mengambil uang yang disimpan dalam celengan tersebut. $^{5}$

\section{Bank Syariah Safir Bengkulu} mempunyai produk unggulan yaitu produk funding celengan di mana pedagang warung dan pelaku usaha kecil menengah (UKM) atau pedagang besar ingin menabung tapi tak ingin pergi ke bank, Bank Syariah Safir Bengkulu langsung datang kewarungwarung untuk menjemput uang yang akan ditabung setiap harinya. Bank Syariah Safir akan meletakkan satu celengan dan akan diambil sesuai kesepakatan pihak pemilik warung. Uang yang di tabung di celengan pada Bank Syariah Safir yang akan kita simpan dengan aman.

Alasan Pemilihan tempat atau lokasi penelitian tersebut dikarenakan BPRS Safir di Jln. Merapi No. 02 Kebun Tebeng Kota Bengkulu. Ini merupakan lembaga keuangan (BANK) yang layak untuk dijadikan mitra usaha dalam

\footnotetext{
${ }^{5}$ Adiwarman Karim, Bank Islam dan Analisis fiqih dan Keuangan, (Jakarta: PT Rajagrafindo Persada. 2004), h. 89
} 
mengembangkan ekonomi produktif melalui prinsip-prinsip syariah. ${ }^{6}$

Pedagang warung adalah pedagang dan pemilik warung, dimana penabung tidak perlu meninggalkan dagangan mereka untuk menabung ke Bank. Karena akan dijemput setiap hari oleh petugas Bank, sehingga memudahkan penabung dalam menjangkau akses tabungan pihak Bank akan memberikan box/kotak celengan kepada penabung, dan secara periodikcelengan akan dibuka petugas Bank dan uang yang terkumpul akan ditabungan di rekening atas nama Nasabah. ${ }^{7}$

Seiring dengan berkembangnya Bank syariah saat ini tidak dipungkiri banyak masyarakat umum yang belum ataupun tidak memahami akan tabungan funding celengan yang dinilai baru. Karena selama ini banyak masyarakat umum hanya mengetahui tabungan konvensional karena jenis ini lebih dahulu muncul dibanding tabungan funding celengan ini.

Inilah yang menjadi tantangan tersendiri bagi Bank syariah pada khususnya untuk memperkenalkan diri kepada masyarakat umum dan sebagai umat muslim juga ikut serta dalam mensosialisasikan tabungan funding

\footnotetext{
${ }^{6}$ Wawancara dengan Amir Mukadar Bank Syari'ah Safir Kota Bengkulu.

${ }^{7}$ Laporan PPL Terstruktur Ekonomi Syariah UIKa di PT BPRS Amanah Ummah: UIKA, 2011.
}

celengan guna memberikan pemahaman baru kepada masyarakat umum. Bahwa tabungan funding celengan lebih memberikan keuntungan, tidak hanya keuntungan duniawi melainkan juga keuntungan akhirat, sebagaimana prinsip syariah dalam bermuamalah. ${ }^{8}$

Berdasarkan observasi awal yang peneliti lakukan terhadap beberapa orang nasabah Bank Safir yang mengikuti program Funding Celengan mereka merasa bahwa program ini membantu dalam dalam hal efektifitas waktu karena bagi mereka lebih baik menjajakan dagangannya dari pada mereka sendiri yang datang ke Bank.

Kemudian peneliti juga melakukan observasi awal di Bank Safir untuk mengetahui jumlah nasabah program Funding Celengan, di dapat data seperti dalam tabel di bawah ini.

Tabel 1 nasabah yang menabung pada funding celengan

\begin{tabular}{|c|c|c|}
\hline No & $\begin{array}{c}\text { Nama } \\
\text { Nasabah }\end{array}$ & $\begin{array}{l}\text { Jumlah } \\
\text { tabungan/tahun }\end{array}$ \\
\hline 1 & Bapak Sahril & Rp. 10.000 .000 \\
\hline 2 & $\begin{array}{l}\text { Bapak } \\
\text { Syafe'i Z }\end{array}$ & Rp. 12.000.000 \\
\hline 3 & Mimi Asti & Rp. 8.000. 000 \\
\hline 4 & Etry & Rp. $\quad 5.000 .000$ \\
\hline 5 & Tono & Rp. 3.500 .000 \\
\hline
\end{tabular}

\footnotetext{
${ }^{8}$ Kasmir. Dasar-Dasar Perbankan, Jakarta: PT Rajagrafindo Persada. 2002. Hlm. 34
} 
Tabel 2 nama petugas bank yang menjadi narasumber

\begin{tabular}{|l|l|l|}
\hline No & $\begin{array}{l}\text { Nama petugas } \\
\text { bank }\end{array}$ & $\begin{array}{l}\text { Jabatan petugas } \\
\text { bank }\end{array}$ \\
\hline 1 & $\begin{array}{l}\text { Marlian } \\
\text { Hamedi }\end{array}$ & $\begin{array}{l}\text { Ka. Div Umum } \\
\text { dan Personalia }\end{array}$ \\
\hline 2 & Nadiyah & Costumer Service \\
\hline 3 & $\begin{array}{l}\text { Syamsul Fajri } \\
\text { Oktario }\end{array}$ & $\begin{array}{l}\text { Ka. Div. Funding } \\
\text { Officer }\end{array}$ \\
\hline 4 & $\begin{array}{l}\text { Periyanto } \\
\text { Faizun }\end{array}$ & Security \\
\hline 5 & Rino Aprian & SPV Pendanaan \\
\hline
\end{tabular}

Sumber: PT. BPRS Safir Bengkulu

Untuk mendukung pembahasan yang lebih mendalam mengenai pembahasan di atas, maka peneliti melakukan kajian pustaka yang berhubungan dengan masalah yang akan dikaji. Adapun pustaka yang terkait dalam hal ini adalah: Penelitian yang dilakukan oleh Noveline sufiana, dengan judul "Perhitungan Bagi Hasil Pada Deposito Investasi Mudharabah di BPRS Artha Amanah Ummat Ungaran" skripsi pada Universitas IAIN Walisongo, Semarang. Pada penelitian ini dijelaskan produk Deposito Investasi Mudharabah pada BPRS Artha Amanah Ummat, yang merupakan pilihan investasi yang menguntungkan bagi nasabah keamananya bila diperlakukan dapat dipergunakan sebagai jaminan pembiayaan, bagi hasil yang kompotitif, serta fasilitas perpanjangan waktu jatuh tempo secara otomatis.

Berbeda dengan penelitian yang dilakukan oleh Evi Natalia, dengan judul “ Pengaruh Tingkat Bagi Hasil Deposito Bank Syariah dan Suku Bunga Deposito Bank Umum Terhadap Jumlah Simpanan Deposito Mudharabah Pada Bank Mandiri Periode 2009-2012", skripsi pada Universitas Beriwijaya, Malang, 2013. Penelitian ini bertujuan untuk mengetahui dan menjelaskan bagaimana pengaruh tingkat bagi hasil deposito bank syariah dan tingkat suku bunga deposito bank umum secara bersama-sama dan prasial terhadap jumlah simpanan deposito mudharabah yang ada di bank syariah.

Annisa syafitri Penelitian pada tahun 2014, Analisis pada produk tabungan iB Hasanah di bank BNI Syariah.Peneliti dengan segala kemampuan yang ada berusaha menelusuri dan menelaah beberapa buku atau karya ilmiah lain yang dapat dijadikan referensi, sumber acuan dan perbandingan dalam membuat penelitian ini. Antara lain : Dalam penelitian ini peneliti menggunakan metode penelitian diskriptif kualitatif. Yang mana hasil penelitiannnya yaitu Pelaksanaan Produk Pemasaran Funding Celengan di BPRS Safir Bengkulu. ditinjau dari hukum positif belum sesuai dengan ketentuan yang sudah ditentukan oleh UMR sedangkan ditinjau 
dari ekonomi Islamnya juga belum sesuai dengan ketentuan belum mencukupi kebutuhan hidup yang bersangkutan, dan mensejahterahkannya.

\section{KAJIAN TEORI}

\section{A. Prinsip Syariah}

Mengenai pelaksanaan prinsip syari'ah dalam produk perbankan secara teknis diatur melalui pasal 2 dan pasal 3 PBI No. 9/19/PBI/2007 tentang pelaksanaan prinsip syari'ah dalam kegiatan penghimpunan dana dan penyaluran dana serta pelayanan jasa Bank syari'ah. Pasal 2 menyatakan bahwa dalam melaksanakan kegiatan penghimpunan dana, yakni dengan memenuhi ketentuan pokok Islam antara lain prinsip keadilan dan keseimbangan ('adl wa tawazun), kemaslahatan (maslahah), dan universalisme (Alamiyah) serta tidak mengandung gharar, mayser , riba, dzalim, riswah, dan objek haram. ${ }^{9}$

Kemudian pasal 3 PBI No. 9/19/PBI/2007 menegaskan bahwa prinsip syari'ah sebagaimna dimksud dalam pasal 2 ayat (1) dilakukan sebagai berikut:

a. Dalam kegiatan penghimpunan dana dengan mempergunakan antara lain Akad Wadi'ah dan Mudharabah.

b. Dalam kegiatan penyaluran dana berupa pembiayaan dengan mempergunakan

\footnotetext{
${ }^{9}$ Abdul Ghofur Anshori, Hukum Perbankan Syari'ah,(PT. Refika Aditama. 2013), h.40
}

anatara lain Akad Mudharabah, Musyarkah, Murabahah, Salam, Istishna, Ijarah, Ijarah Muntayah Bitamlik dan Qardh.

c. Dalam kegiatan pelayanan jasa dengan mempergunakan antara lain Akad Kafalah, Hawalah, dan Sharf.

Berdasarkan pada Pelayanan Bank Indonesia (PBI) dimksud kegiatan usaha bank syari'ah juga diklasifikasikan menjadi 3 macam, yaitu kegiatan penghimpunan dana, kegiatan penyaluran dana, dan kegiatan pelayanan jasa. Teknis dari kegiatan-kegiatan dimaksud diatur lebih lanjut melalui Surat Edaran Bank Indonesia (SEBI) No. 10/14/DPbS Jakarta, 17 Maret 2009 prihal pelaksanaan prinsip syari'ah dalam kegiatan penghimpunan dana dan penyaluran dana serta pelayanan jasa bank syari'ah. ${ }^{10}$

Pelaksanaan adalah tindakan atau pelaksanaan dari sebuah rencana yangsudah disusun secara matang dan terperinci, implementasi biasanya dilakukan setelah perencanaan sudah dianggap siap. Secara sederhana pelaksanaan bisa diartikan penerapan. Majoe dan Wildavsky mengemukakan pelaksanaan sebagai evaluasi. Browne dan Wildabsky mengemukakan bahwa pelaksanaan adalah perluasan aktivitas yang saling

\footnotetext{
${ }^{10}$ Abdul Ghofur Anshori, Hukum Perbankan Syari'ah,(PT. Refika Aditama. 2013), h.41
} 
menyesuaikan. ${ }^{11}$

Menurut Wahab Pelaksanaan atau implementasi sebagai berikut:

"Implementasi adalah tindakantindakan yang dilakukan oleh individu atau pejabat-pejabat, kelompok-kelompok pemerintah atau swasta yang diarahkan pada terciptanya tujuan-tujuan yang telah digariskan dalam keputusan kebijakan”.

Pengertian-pengertian di atas memperlihatkan bahwa kata pelaksanaan bermuarapada aktivitas, adanya aksi, tindakan, atau mekanisme suatu sistem. Ungkapanmekanisme mengandung arti bahwa pelaksanaan bukan sekedar aktivitas, tetapisuatu kegiatan yang terencana dan dilakukan secara sungguhsungguhberdasarkan norma tertentu untuk mencapai tujuan kegiatan.

Pelaksanaan merupakan aktifitas atau usaha-usaha yang dilaksanakan untuk melaksanakan semua rencana dan kebijaksanaan yang telah dirimuskan danditetapkan dengan dilengkapi segala kebutuhan, alat-alat yang diperlukan, siapayang melaksanakan, dimana tempat pelaksanaannya mulai dan bagaimana carayang harus dilaksanakan, suatu proses rangkaian kegiatan tindak lanjut setelah program atau kebijaksanaan ditetapkan yang terdiri atas pengambilan

11 Nurdin Usman, Konteks Implementasi Berbasis Kurikulum, (Jakarta:PT.Raja Grafindo persada. 2002), h. 70 keputusan,langkah yang strategis maupun operasional atau kebijaksanaan menjadikenyataan guna mencapai sasaran dari program yang ditetapkan semula. ${ }^{12}$

Dari pengertian yang dikemukakan di atas dapatlah ditarik suatu kesimpulan bahwa pada dasarnya pelaksanaan suatu program yang telah ditetapkan oleh pemerintah harus sejalan dengan kondisi yang ada, baik itu di lapangan maupun di luar lapangan. Yang mana dalam kegiatannya melibatkan beberapa unsur disertai dengan usaha-usaha dan didukung oleh alat-alat penujang.

Menurut wahab faktor-faktor yang dapat menunjang program pelaksanaan adalah sebagai berikut:

a. Komunikasi, merupakan suatu program yang dapat dilaksanakan dengan baik apabila jelas bagi para pelaksana. Hal ini menyangkut proses penyampaian informasi, kejelasan informasi dan konsistensi informasi yang disampaikan;

b. Resources (sumber daya), dalam hal ini meliputi empat komponen yaitu terpenuhinya jumlah staf dan kualitas mutu, informasi yang diperlukan guna pengambilan keputusan atau kewenangan yang cukup guna melaksanakan tugas sebagai tanggung

${ }^{12}$ Achmad Rusyaidi H, Pengadaan Tanah Untuk Kepentingan Umum: Antara Kepentingan Umum dan Perlindungan Hak Asasi Manusia. 2009 
jawab dan fasilitas yang dibutuhkan dalam pelaksanaan.

c. Disposisi, sikap dan komitmen dari pada pelaksanaan terhadap program khususnya dari mereka yang menjadi implementasi program khususnya dari mereka yang menjadi implementer program;

d. Struktur Birokrasi, yaitu SOP (Standar Operating Procedures), yang mengatur tata aliran dalam pelaksanaan program. Jika hal ini tidak sulit dalam mencapai hasil yang memuaskan, karena penyelesaian khusus tanpa pola yang baku.

\section{B. Produk}

Produk merupakan pusat dari kegiatan pemasaran, karena produk merupakan hasil usaha dari perusahaan, yang dapat di tawarkan di pasar untuk memenuhi kebutuhan konsumen. Produk juga merupakan alat dari suatu perusahaan agar perusahaan tersebut dapat mencapai tujuan. Setiap produk harus mempunyai keunggulan dari masing-masing produk itu sendiri, mulai dari kualitas, Desain, kemasan, bentuk, garansi, dan ras agar dapat menarik minat masyarakat untuk membeli produk tersebut.

Produk yang dihasilkan oleh dunia usaha pada umumnya berbentuk dua macam, yaitu produk yang berwujud dan produk yang tidak berwujud. Masing- masing produk untuk dapat dikatakan berwujud atau tidak berwujud memiliki karakteristik tertentu. Produk yang berwujud berupa barang dpat dilihat, dipegang, dan dirasakan secara langsung oleh konsumen sebelum membeli. Contoh barang berwujud misalnya dompet kulit dimana kita bisa merasakan jenis kulitnya apakah bagus atau buruk. Smentara produk yang tidak berwujud berupa jasa dimana tidak dapat dilihat atau dirasa oleh konsumen sebelum membeli, contoh produk yang tidak berwujud misalnya jasa pangkas rambut dimana kita tidak bisa merasakan sebelum kita menggunkan jasa pangkas rambut tersebut. Contoh lain dari produk yang tidak berwujud adalah pelayanan jasa perbankan. ${ }^{13}$

Menurut Syamsul Fajri Oktorio selaku Kepala Divisi Pendanaan Bank Syari'ah Safir mengatakan produk yang ada pada Bank Syari'ah Safir ada emapat produk yaitu:

1) Produk Tabungan Wadiah Warung dan Toko

2) Produk Tabungan Wadiah Pasar

3) Produk Tabungan Wadiah Safir /Umum

4) Produk Tabungan Wadiah Pelajar

Yang mana produk yang unggul pada Bank Syari'ah Safir ini adalah tabungan wadiah Warung atau Funding

${ }^{13}$ M. Nur Rianto Al Arif, Dasar-dasar Pemasaran Bank Syariah, Bandung: Alfabeta. 2012.h. 139 
Celengan karena tabungan tersebut hanya untuk warung saja.

\section{Pemasaran}

Apabila terdengar kata pemasran seringkali dikaitkan oleh banyak pihak dengan penjualan (sales), sales promotion girl, iklan, promosi, atau produk. Bahkan seringkali orang menyamakan profesi marketer (pemasar) denagan sales (penjual). Namun sebenarnya pemasaran tidaklah sesempit yang diidentikkan oleh banyak orang, karena pemasaran berbeda dengan pemjualan. Pemasaran lebih merupakan "suatu seni menjual produk", sehingga pemasaran proses penjualan yang dimulai dari perancangan produk sampai dengan setelah produk tersebut terjual. Berbeda dengan penjualan yang hanya berkutat pada terjadinya transaksi penjualan barang atau jasa.

Dunia pemasaran sering pula diidentikkan dunia yang penuh janji manis namun belum tentu terbukti apakah produknya sesuai dengan apa yang telah dijanjikan. ${ }^{14}$ Inilah yang harus dibuktikan dalam suatu manajemen pemasaran syariah baik pada penjualan produk barang atau jasa, bahwa pemasaran syariah bukanlah dunia yang penuh dengan tipu menipu. Sebab pemasaran syariah merupakan tingkatan paling tinggi dalam pemasaran,

${ }^{14}$ M. Nur Rianto Al Arif, Dasar-dasar Pemasaran Bank Syariah, Bandung: Alfabeta. 2012.h. 4-6 yang spiritual marketing, dimana etika, nilai-nilai dan norma dijunjung tinggi. Halhal inilah yang seringkali dilanggar oleh dalam pemasaran konvensional, sehingga menyebabkan konsumen pada akhirnya banyak yang kecewa pada produk barang atau jasa yang telah dibeli karena berbeda dengan apa yang telah dijanjikan oleh para pemasar.

Apa yang membedakan pemasar Bank dengan pemasaran produk lainnya. Tidak ada yang terlalu membedakan antara pemasaran Bank dengan pemasaran lainnya, melainkan karakteristik produknya, dimana produk yang dijual oleh Bank adalah lebih bersifat jasa dan bukan barang. Sehngga produk yang yang dijual sedikit abstrak atau tidak dapat dilihat secara nyata namun tetap dapat dirasakan oleh nasabah. Karena perbedaan strategi pemasaran yang diterapkan haruslah yang tepat yaitu strategi pemasaran bagi produk jasa. Pemasaran berhubungan dasn berkaitan denagn suatu proses mengidentifikasikan dan memenuhi kebutuhan manusia dan masyarakat. Slah satu dari definisi pemasaran yang terpendek adalah "memenuhi kebutuhan secara menguntungkan".

Dari definisi tersebut di atas, dapat ditarik kesimpulan bahwa pemasaran merupakan usaha terpadu untuk menggabungkan rencana-rencana strategis yang diarahkan kepada usaha pemuas 
kebutuhan dan keinginan konsumen untuk memperoleh keuntungan yang diharapkan melalui proses pertukaran atau transaksi. Kegiatan pemasaran perusahaan harus dapat memberikan kepuasan kepada konsumen bila ingin mendapatkan tanggapan yang baik dari konsumen.Perusahaan harus secara penuh tanggung jawab tentang kepuasan produk yang ditawarkan tersebut.Dengan demikian, maka segala aktivitas perusahaan, harusnya diarahkan untuk dapat memuaskan konsumen yang pada akhirnya bertujuan untuk memperoleh laba.

\section{Pengertian Funding}

Funding adalah kegiatan menghimpun dana dari nasabah atau calon nasabah yang berbentuk simpanan atau penyertaan modal guna penguatan modal kedalam.Salah satu karakteristik lembaga keuangan syari'ah adalah adanya mekanisme titipan. Mekanisme lembaga keuangan syari'ah dengan menggunakan sistem titipan akan menjadi salah satu alternatif bagi masyarakat bisnis, karena mekanisme tersebut sangat berbeda dengan mekanisme ekonomi konvensional yang menggunakan instrumen bunga Kegiatan funding adalah mengumpulkan dana dari masyarakat kegiatan ini menawarkan berbagai cara dengan berbagai jenis simpanan. $^{15}$

Menurut Undang-undang perbankan syari'ah No. 21 tahun 2008, tabungan adalah simpanan berdasarkan Akad Wadhi'ah atau investasi dana berdasarkan Mudharabah atau akad lain yang tidak bertentangan dengan prinsip syariah yang penarikannya dapat dilakukan menurut syarat dan ketentuan tertentu yang disepakati, tetapi tidak dapat ditarik dengan cek, bilyet giro, dan/ atau alat lainnya yang dipersamakan dengan itu. ${ }^{16}$

\section{E. Pengertian Celengan}

Celengan merupakan nama umum untuk kotak akumulasi atau penabungan koin. Umumnya, celengan digunakan oleh anak-anak. Celengan biasanya terbuat dari keramik atau porselen. Celengan bertujuan untuk mengajarkan kepada anak untuk menabung. Pada celengan tradisional, uang dapat dengan mudah dimasukkan, namun jika ingin mengambil uangnya, celengan tersebut harus dipecahkan. Tapi celengan modern memiliki lubang karet pada bagian bawahnya, untuk memudahkan dalam mengambil uang yang disimpan dalam celengan tersebut. ${ }^{17}$

\section{F. Funding Celengan}

15 Muhammad., Manajemen Dana Bank Syari'ah, (Yogyakarta: Ekonesia. 2004), h. 78

${ }^{16}$ M. Nur Rianto Al Arif, Dasar-dasar Pemasaran Bank Syari'ah, (Bandung: Alfabeta. 2012), h.34

${ }^{17}$ Muhammad Yusuf, Junaed, Pengantar Ilmu Ekonomi dan Perbankan Syariah, (Jakarta: Ganeca Press. 2006), h. 65 
Marketing Funding sendiri menghendaki. ${ }^{19}$ Wadiah juga dapat juga bertanggungjawab pada pencapaian target diartikan sebagai amanat yang ada pada bidang usaha Funding (Pendanaan). orang yang dititipi dan ia wajib Seorang marketing Funding akan diberikan mengembalikkannya pada saat pemilik target dari suatu bank yang mempekerjakannya untuk dapat meminta. Adapun dasar hukum wadiah menghimpun dana sebanyak-banyaknya dari nasabah. Dana dapat berasal dari beberapa produk bank diantara melalui simpanan tabungan, maupun simpanan deposito dari para nasabahnya. Suatu fungsi jabatan pekerjaan biasanya di sebuah Bank mempromosikan dan juga menghimpun dana dari masyarakat. ${ }^{18}$ Dalam hal ini seorang marketing funding biasanya sudah mendapatkan daftar nama yang berpotensi untuk menitipkan dananya pada bank (Menabung).Didalam dunia perbankan fungsi jabatan marketing funding juga sering disebut dengan Funding Officer. Sebagian besar waktu kerjanya dihabiskan dilapangan, atau sangat jarang sekali ditemui atau berada di dalam kantor.

\section{G. Akad Wadhi'ah}

Pada Bank Syariah wadiah merupakan titipan atau simpanan. Prinsip wadiah merupakan titipan murni dari satu pihak ke pihak lain, bagi perseorangan maupun badan hukum yang harus dijaga dan dikembalikan kapan saja bila si penitip

${ }^{18}$ Nasution, Metodologi Research Penelitian Ilmiah, (Jakarta: Bumi Aksara. 2003), h. 23

QS:An-Nisa(04):58 yang artinya :

"Sesungguhnya Allah menyuruh kamu menyampaikan amanat kepada yang berhak menerimanya, dan (menyuruh kamu) apabila menetapkan hukum di antara manusia supaya kamu menetapkan dengan adil. Sesungguhnya Allah memberi pengajaran yang sebaik-baiknya kepadamu. Sesungguhnya Allah adalah Maha mendengar lagi Maha melihat”.

Fatwa wadhiah yaitu DSN MUI NO:02/DSN-MUI/2000, tabungan ada dua jenis, yaitu : pertama, tabungan yang tidak dibenarkan secara prinsip syariah yang berupa tabungan dengan berdasarkan perhitungan bunga. Kedua, tabungan yang dibenarkan secara prinsip syariah yakni tabungan berdasarkan prinsip mudharabah dan wadhi'ah. tentang tabungan yang memperbolehkan nasabah dalam menggunakan produk tersebut. Salah satu prinsip yang digunakan bank syariah dalam penghimpunan dana adalah dengan menggunakan prinsip titipan. ${ }^{20}$ Adapun akad yang sesuai dengan prinsip ini adalah Al-Wadhi'ah. Al-wadhiah merupakan

19 Fatwa Dewan Syariah Nasionaln No.03/DSN-MUI/IV/2000.

${ }^{20}$ Undang-Undang Republik Indonesia No. 21 Tahun 2008 tentang Perbankan Syariah 
titipan murni yang setiap saat dapat diambil jika memilikinya menghendaki. $^{21}$

Wadhi'ah menurut bahasa adalah berasal dari akar kata wada'a yang berarti meninggalkan titipan. Menurut bank indonesia adalah akad penitipan barang/uang dengan pihak yang diberi kepercayaan dengan tujuan untuk mencegah keselamatan, keamanan serta ketuhanan barang/uang. Wadiah merupakan titipan atau simpanan pada bank syariah. Prinsip wadhiah merupakan titipan murni dari satu pihak ke pihak lain, baik perorangan maupubadan hukum yang mau dijaga dan dikembalikan kepan saja bila si penitip menghendaki.

\section{Alur Pembiayaan Murabahah}

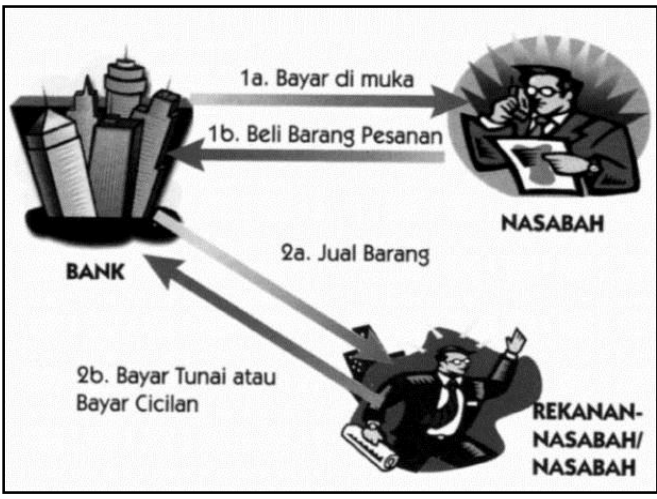

Sumber: PT. BPRS Safir Bengkulu (2016)

a. Transaksi pembiayaan yang ditujukan untuk mendapatkan jasa dilakukan dengan prinsip sewa yang ada

${ }^{21}$ M. Nur Rianto Al Arif, Dasar-dasar Pemasaran Bank Syariah, Bandung: Alfabeta. 2012.h. 34 diterapkan di PT.BPRS Safir Bengkulu yakni Prinsip Ijarah :

Transaksi ijarah dilandasi adanya perpindahaan manfaat. Jadi pada dasarnya prinsip ijarah sama saja dengan prinsip jual beli, namun perbedaannya terletak pada objek transaksinya. Bila pada jual beli objek transaksinya adalah barang, maka pada ijarah objek transaksinya adalah jasa.

\section{Alur Pembiayaan dengan Prinsip Ijarah}

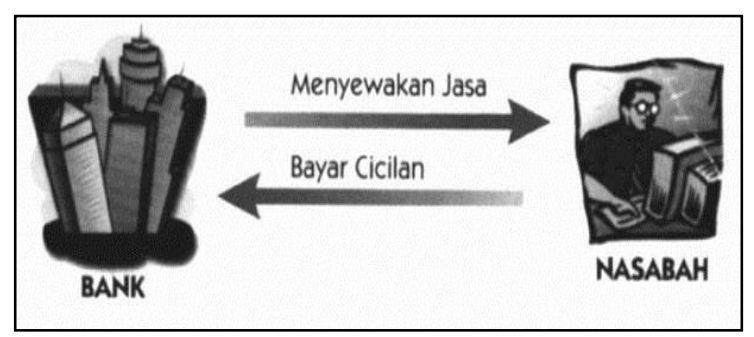

Sumber: PT. BPRS Safir Bengkulu

Pada akhir masa sewa, bank dapat saja menjual barang yang disewakannya kepada nasabah. Karena itu dalam perbankan syariah dikenal ijarah muntahhiyah bittamlik (sewa yang diikuti dengan berpindahnya kepemilikan). Harga sewa dan harga jual disepakati pada awal perjanjian.

b. Transaksi pembiayaan untuk usaha kerjasama yang ditujukan guna mendapatkan sekaligus barang dan jasa, dengan prinsip bagi hasil yang terjadi di PT BPRS Safir Bengkulu yakni Pembiayaan Musyarakah. 
Bentuk umum dari usaha bagi hasil adalah musyarakah (syirkah atau syarikah atau serikat atau kongsi).

Transaksi musyarakah dilandasi adanya keinginan para pihak yang bekerjasama untuk meningkatkan nilai asset yang mereka miliki secara bersama-sama. Termasuk dalam golongan musyarakah adalah semua bentuk usaha yang melibatkan dua pihak atau lebih dimana mereka secara bersama-sama memadukan seluruh bentuk sumber daya baik yang berwujud maupun tidak berwujud.

Secara spesifik bentuk kontribusi dari pihak yang bekerjasama dapat berupa dana, barang perdagangan (trading asset), kewiraswastaan

(entrepreneurship), kepandaian (skill), kepemilikan (property), peralatan (equipment), atau intangible asset (seperti hak paten atau goodwill), kepercayaan/reputasi (credit worthiness) dan barang-barang lainnya yang dapat dinilai dengan uang. Dengan merangkum seluruh kombinasi dari bentuk kontribusi masing-masing pihak dengan atau tanpa batasan waktu menjadikan produk ini sangat fleksibel.
Alur Pembiayaan Musyarakah

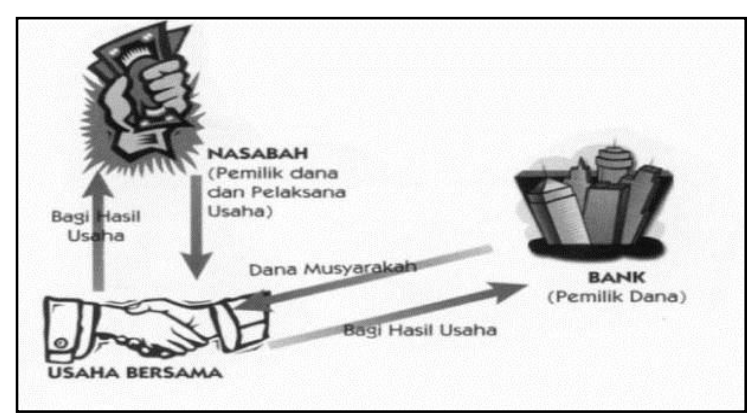

Sumber: PT. BPRS Safir Bengkulu

Semua modal disatukan untuk dijadikan modal proyek musyarakah dan dikelola bersama-sama. Setiap pemilik modal berhak turut serta dalam menentukan kebijakan usaha yang dijalankan oleh pelaksana proyek. Pemilik modal dipercaya untuk menjalankan proyek musyarakah tidak boleh melakukan tindakan seperti:

a) Menggabungkan dana proyek dengan harta pribadi.

b) Menjalankan proyek musyarakah dengan pihak lain tanpa ijin pemilik modal lainnya.

c) Memberi pinjaman kepada pihak lain.

Setiap pemilik modal dapat mengalihkan penyertaan atau digantikan oleh pihak lain.Setiap pemilik modal dianggap mengakhiri kerjasama apabila:

1) Menarik diri dari perserikatan

2) Meninggal dunia,

3) Menjadi tidak cakap hukum

Biaya yang timbul dalam pelaksanaan proyek dan jangka waktu proyek harus diketahui bersama. Keuntungan dibagi sesuai kesepakatan 
sedangkan kerugian dibagi sesuai dengan porsi kontribusi modal.Proyek yang akan dijalankan harus disebutkan dalam akad. Setelah proyek selesai nasabah mengembalikan dana tersebut bersama bagi hasil yang telah disepakati untuk Bank.

c. Transaksi Rahn dan Qordh

Tujuan akad rahn adalah untuk memberikan jaminan pembayaran kembali kepada bank dalam memberikan pembiayaan.Barang yang digadaikan wajib memenuhi kriteria :

a) Milik nasabah sendiri.

b) Jelas ukuran, sifat, dan nilainya ditentukan berdasarkan nilai riil pasar.

c) Dapat dikuasai namun tidak boleh dimanfaatkan oleh bank. Atas izin bank, nasabah dapat menggunakan barang tertentu yang digadaikan dengan tidak mengurangi nilai dan merusak barang yang digadaikan. Apabila barang yang digadaikan rusak atau cacat, maka nasabah harus bertanggungjawab.

Apabila nasabah wanprestasi, bank dapat melakukan penjualan barang yang digadaikan atas perintah hakim. Nasabah mempunyai hak untuk menjual barang tersebut dengan seizin bank. Apabila hasil penjualan melebihi kewajibannya, maka kelebihan tersebut menjadi milik nasabah. Dalam hasil penjualan tersebut lebih kecil dari kewajibannya, nasabah menutupi kekurangannya.
Qardh adalah pinjaman uang. Aplikasi qardh dalam PT BPRS Safir Bengkulu biasanya dalam dua hal, yaitu :

1. Sebagai pinjaman kepada pengusaha kecil, dimana menurut perhitungan bank akan memberatkan si pengusaha bila diberikan pembiayaan dengan skema jual beli, ijarah, atau bagi hasil.

2. Sebagai pinjaman kepada pengurus bank, dimana bank menyediakan fasilitas ini untuk memastikan terpenuhinya kebutuhan pengurus bank. Pengurus bank akan mengembalikannya secara cicilan melalui pemotongan gajinya.

\section{Produk Penghimpunan Dana}

Penghimpunan dana di Bank pembiayaan Rakyat Syariah safir dapat berbentuk tabungan dan deposito. Prinsip operasional syariah yang diterapkan dalam penghimpunan dana masyarakat adalah prinsip wadiah dan mudharabah.

\section{a. Prinsip Wadiah}

Prinsip Wadi'ah yang diterapkan adalah wadi'ah amanah dalam wadiah amanah, pada prinsipnya harta titipan tidak boleh dimanfaatkan oleh yang dititipi. Tetapi jika dana tersebut digunakan, maka keuntungan atau kerugian dari penyaluran dana menjadi hak milik atau ditanggung bank, sedang pemilik dana tidak dijanjikan imbalan dan tidak menanggung kerugian. Bank dimungkinkan memberikan bonus kepada pemilik dana sebagai suatu 
insentif untuk menarik dana masyarakat namun tidak boleh diperjanjikan di muka. Bank harus membuat akad pembukaan rekening yang isinya mencakup izin penyaluran dana yang disimpan dan persyaratan lain yang disepakati selama tidak bertentangan dengan prinsip syariah. Tabungan Wadiah PT.BPRS Safir Bengkulu terdiri dari :

1) Tabungan Wadiah Bank Syariah Safir Tabungan Wadiah Umum

Tabungan ini menunjuk sasaran pada masyarakat umum, dalam komponen tabungan ini terdiri dari tabungan umum, tabungan bagi hasil deposan serta tabungan dalam pendebetan angsuran pembiayaan.

2) Tabungan Wadiah Bank Syariah Safir Tabungan Wadiah Pelajar

Tabungan ini dikemas dengan melaukan kerjasama terpadu kepada sekolah-sekolah dengan dasar sebagai media edukasi kepada anak-anak tentang menabung sejak dini. Sistem yang digunakan adalah sistem jemput bola, dimana tabungan akan dijemput dan kembali diantar secara berkala dan berkontiniu sesuai kesepakatan dengan pihak sekolah.

3) Tabungan Wadiah Bank Syariah SafirTabungan Wadiah Haji dan Qurban.

Diperuntukan sebagai sarana penyimpanan dan tidak menyediakan pemberangkatan haji. Sedangkan tabungan qurban memiliki sasaran kelompok-kelompok qurban pada beberapa jamaah masjid.

4) Tabungan Wadiah Bank Syariah Safir Tabungan Wadiah Pasar

Tabungan ini merupakan bentuk kepedulian atas kurangnya manfaat dan akses bank pada masyarakat terutama pedagang pasar. Hadirnya safir dalam produk tabungan pasar ini memberi peluang yang luas kepada para pedagang dipasar yang selama ini enggan menabung dengan langsung datang ke bank.

5) Tabungan Wadiah Bank Syariah Safir Tabungan Wadiah Warung

Dengan banyaknya warung yang tersebar memberikan peluang atas potensi yang besar dalam penghimpunan dana murah. Kegiatan ini dilakukan dengan penjemputan secara rutin secara berkala sesuai dengan kesepakatan.

Nilai Tabungan Wadiah Safir :

a) Sebagai media edukasi kepada masyarakat atas manfaat menabung

b) Melatih menabung sejak dini melalui tabungan pelajar

c) Melayani dengan sepenuh hati dengan bersentuhan langsung kepada masyarakat

d) Membantu memberi kesempatan kepada masyarakat untuk mendapat manfaat 
menabung melalui antar jemput tabunganSebagai media promosi yang efektif.

b. Prinsip Mudharabah

\section{Dalam} mengaplikasikan prinsip mudharabah, penyimpan atau deposan bertindak sebagai shahibul maal (pemilik modal) dan bank sebagai mudharib (pengelola). Dana tersebut digunakan bank untuk melakukan pembiayaan murabahah atau ijarah seperti yang telah dijelaskan terdahulu. Hasil usaha ini akan dibagi hasilkan berdasarkan nisbah yang disepakati. Dalam hal bank menggunakannya untuk melakukan pembiayaan mudharabah, maka bank bertanggungjawab penuh atas kerugian yang terjadi.

Rukun mudharabah terpenuhi sempurna (ada mudharib - ada pemilik dana, ada usaha yang akan dibagi hasilkan, ada nisbah, ada ijab kabul). Prinsip mudharabah ini diaplikasikan pada deposito berjangka.

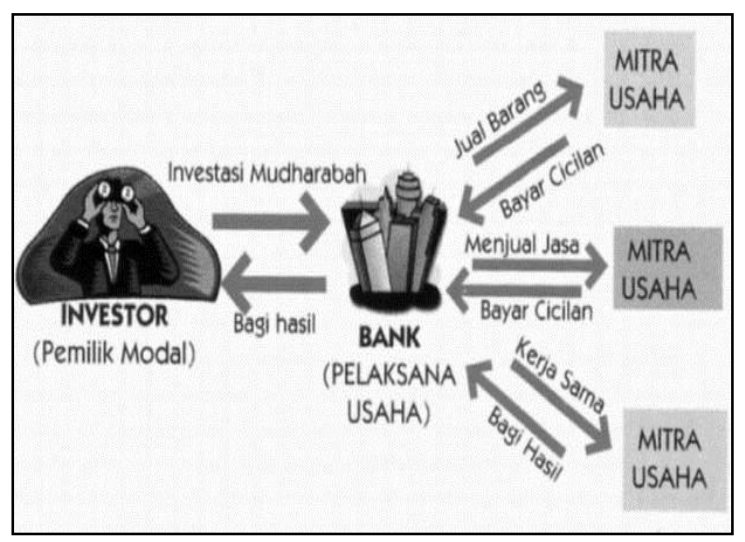

Gambar: Alur Penggunaan Dana Deposito Sumber: PT. BPRS Safir Bengkulu

Deposito mudharabah hanya dapat dicairkan sesuai dengan jangka waktu yang telah disepakati. Deposito yang diperpanjang, setelah jatuh tempo akan diperlakukan sama seperti deposito baru, tetapi bila pada akad sudah dicantumkan perpanjangan otomatis maka tidak perlu dibuat akad baru.Ketentuan-ketentuan yang lain yang berkaitan dengan tabungan dan deposito tetap berlaku sepanjang tidak bertentangan dengan prinsip syariah.

\section{Sumber Daya Manusia}

Sampai Desember 2015, jumlah karyawan/ti PT. BPRS Safir Bengkulu adalah 99 orang, dengan jumlah karyawan Pria (P) 60 Orang dan karyawan Wanita (W) 39 Orang, dengan rincian:

a) Kantor Pusat : 50 Orang $(\mathrm{P}=32, \mathrm{~W}=18)$

b) Kantor Cabang Ketahun : 15 Orang $(\mathrm{P}=9, \mathrm{~W}=4)$

c) Kantor Cabang Curup : 17 Orang $(\mathrm{P}=9, \mathrm{~W}=8)$

d) Kantor Cabang Manna : 17 Orang $(\mathrm{P}=10, \mathrm{~W}=7)$

\section{METODOLOGI PENELITIAN}

\section{Jenis dan Pendekatan Penelitian}

Jenis Penelitian dalam skripsi ini adalah penelitian lapangan. Untuk mendapatkan data yang diperlukan dalam 
penyelesaian skripsi ini, peneliti melakukan penelitian ini menggunakan metode pengumpulan data dengan peninjauan langsung kepada objek penelitian dilapangan dalam hal ini funding celengan pada Bank Safir Kota Bengkulu. Hal ini dilakukan untuk memperoleh data yang relevan dengan tujuan penelitian secara nyata tepat dan akurat.

Pendekatan ini dilakukan dengan menggunakan pendekatan penelitian kualitatif karena maksud dari penelitian ini bertujuan untuk mengetahui bagaimana Pelaksanaan funding celengan di Bank Safir menyelesaikan berbagai masalah. ${ }^{22}$

\section{Waktu dan Lokasi Penelitian}

Penelitian ini dilakukan di BPRS Safir Bengkulu yang terletak di Jln.Merapi No. 02 Kebun Tebeng Kota Bengkulu. Telp. 0736-346994 fax. 0736-346974. Pemilihan lokasi tersebut didasarkan karena BPRS Safir Kota Bengkulu ini merupakan lembaga keuangan (BANK) yang layak untuk dijadikan mitra usaha dalam mengembangkan ekonomi produktif melalui prinsip-prinsip syariah. Penelitian ini dilaksanakan terhitung sejak bulan Oktober 2016 sampai Desember 2017.

\section{Subjek/ Informan Penelitian}

Yang menjadi objek penelitian yaitu Nasabah dan karyawan bank BPRS

${ }^{22}$ Hendri Tanjung, Metodologi Penelitian, ( Bogor: UIKA Press. 2012), h. 89
Safir Bengkulu, dan jumlah nasabah yang menabung pada funding celengan ada 50 orang tetapi yang menjadi narasumber untuk di wawancarai 5 orang nasabah dan 5 orang karyawan bank BPRS Safir Bengkulu.

\section{Sumber dan Teknik Pengumpulan Data}

Suatu penelitian juga dibutuhkan sumber data untuk mempermudah dalam memecahkan suatu masalah. Dan yang digunakan dalam penelitian ini adalah data primer dan data skunder.

\section{a) Data Primer}

Data primer adalah data yang dikumpulkan secara langsung dari lapangan penelitian. Data ini juga diperoleh dari responden melalui wawancara dengan narasumber.Yang menjadi objek penelitian, Nasabah 5 orang yaitu, Mimi, Asti, Etry, Saibah,Tono dan 5 orang karyawan bank yaitu, Marlian Hamedi Ka. Div Umum Personalia, Nadiah Costumer Service, Syamsul Fajri Oktorio Ka. Div FundingOfficer, Rino Aprian SPV Pendanaan, Ramadhanti elsa Head Teller.

\section{b) Data Skunder}

Data yang diperoleh secara tidak langsung dari narasumber. Data skunder dalam penelitian ini adalah 
berupa formulir, brosur, dan modul tentang produk BPRS Safir Bengkulu.

Beberapa teknik pengumpulan data yang digunakan peneliti antara lain:

b) Wawancara

Wawancara yaitu teknik pengumpulan data dengan cara melakukan tanya jawab dengan petugas, pegawai, dan otoritas (pihak yang berwenang) tentang pelaksanaan funding celengan BPRS. ${ }^{23}$ Safir Kota Bengkulu. Metode ini digunakan untuk menggali data dan meminta pertimbangan berbagai pihak agar tidak terjadi penyimpangan atau salah pergertian mengenai permaslahan yang diangkat dalam tema penelitian ini.

c) Observasi

Observasi, yaitu metode ini dilakukan dengan cara mengamati secara langsung terhadap objek tertentu dengan mengetahui suasana kerja mengenai pelaksanaan fanding celengan BPRS. Safir Bengkulu.

\section{d) Dokumentasi}

Metode dokumentasi adalah mencari data yang mengenai hal-hal atau variabel yang berupa catatan. Transkip, buku,surat kabar, majalah,

\footnotetext{
${ }^{23}$ BPRS Amanah Ummah, Laporan Tahunan 2012
}

nutolen rapat, kamera, agenda dan sebagainya.

\section{Teknik Analisis Data}

Analisis data yang di gunakan adalah deskriptif analisis data yang di wujudkan bukan dalam bentuk angka melainkan dalam bentuklaporan dan uraian dalam bentuk deskriptif. Metode ini bertujuanuntuk membuat deskripsi, gambaran atau lukisan secara sistematikfactual dan akurat tentang faktorfaktor, sifat-sifat tentang hubunganantara fenomena yang di selidiki, penelitian ini bertujuan untukmenganalisis data tentang Pelaksanaan Produk Pemasaran Funding Celengan di BPRS Safir Bengkulu.

\section{PEMBAHASAN}

\section{A. Hasil Penelitian}

\section{Pelaksanaan Funding Celengan di BPRS Safir Bengkulu}

Berdasarkan hasil wawancara dengan Merlian Hamedi, S.E sebagai Kepala Divisi Umum dan Personalia di PT. BPRS Safir Bengkulu Pada bagian ini, penullis akan memaparkan hasil penelitian yang telah didapat dari lapangan berkaitan dengan Pelaksanaan Produk Pemasaran Funding Celengan BPRS Safir Bengkulu adalah sebagai berikut :

Jadi yang melatar belakangi yaitu karena masih minimnya UMKM yang 
mendapatkan pendanaan dari perbankan, harus dipatuhi bagi penabung melalui mereka masih banyak memperoleh dari tengkulak dan kerabat yang tentunya akan mempersulit mereka dalam memperoleh maupun mengembalikannya.

a. Bagaimana cara mengajukan funding celengan ini?

"Dalam proses pengajuan funding celengan kita harus musyawarah dulu dengan OJK nanti kalau sudah disetujui oleh pihak OJK, kita langsung menyebarkan kotak celengan kewarungwarung yang mau menabung. Dan berapa orang marketingnya yang akan menyebarkan kotak celengan, nah kita diskusikan dulu lewat personalia. Dengan demikian funding celengan dapat dilaksanakan setelah dapat persetujuan dari Otoritas Jasa Keuangan. "24

Adapun prosesnya yaitu dengan cara menyebarkan celengan kewarungwarung yang mau menabung dan selanjutnya ada kesepakatan antara penabung dan petugas kami mengenai sistem menabungnya.

b. Apa yang menjadi hak dan kewajiban para pihak dalam funding celengan ini?

Berdasarkan hasil wawancara peneliti dengan beberapa responden didapat data bahwa ada hak dan kewajiban yang

\footnotetext{
${ }^{24}$ Marlian Hamedi. (Ka. Div Umum dan Personalia), Wawancara 06 Maret 2017
}

Funding Celengan.

Bardasarkan apa yang di sampaikan divisi pendanaan Bank Safir Bengkulu yaitu:

"Ya, kita punya kewajiban tabungan tadi dimasukkan di dalam kotak celengan tadi, hari apa uangnya mau dijemput sesuai dengan perjanjian dari awal marketing dengan nasabah, kotak atau celangan tetap diwarung tapi kuncinya pihak bank yang megangnya atau yang menyimpan kuncinya. Pas nasabah mau ngambil uangnya petugas bank dan nasabah buka sama-sama, tabungan kamu dalam minggu ini misalnya Rp. 100,- nanti kita kasih slipnya, hak layanannya dan kamu yang menyerahkan uangnya. ${ }^{25}$

Jadi, pengamatan peneliti memang ada hak dan kewajiban yang harus dilakukan oleh para penabung dan juga oleh petugas dalam hal funding celengan ini penabung harus melakukan proses penabungan dengan cara mengisi celengan dan akan diambil oleh petugas sesuai dengan kesepakatan sebelumnya antara penabung dan petugas dari Bank Safir Bengkulu.

\footnotetext{
${ }^{25}$ Marlian Hamedi. (Ka. Div Umum dan Personalia), Wawancara 01 Maret 2017
} 
c. Bagaimana penentuan pengambilan keuntunganfunding celengan yang dipraktekkan di Bank Safir Bengkulu?

Berdasarkan hasil wawancara dengan karyawan Bank Safir Bengkulu mengungkapkan bahwa :

"Ini untuk tabungan, nah misalnya sistem bonus nasabah menabung setiap akhir bulan ada yang namanya pembagian bonus tapi kita tidak bisa menentukkannya besar kecilnya dikomputer sendiri yang menentukkannya disesuaikan dengan tabungan nasabah., 26

Berdasarkan hasil wawancara dengan apa yang disampaikan oleh nasabah yang menabung pada funding celengan bahwa besarnya bonus sudah diatur sistem dan disesuaikan dengan besarnya tabungan yang dilakukan oleh nasabah sendiri.

d. Apakah ada jadwal khusus di setiap penjemputan uang yang akan ditabung untuk produk funding celengan pada Bank Safir Bengkulu?

Berdasarkan hasil wawancara dengan karyawan Bank Safir Bengkulu mengungkapkan bahwa :

"Nah itu tadi kita tentukan bersama dan harus komitmen sesuai dengan perjanjian nasabah dan pihak bank, kapan nasabahnya mau dijemput uangnya, mau hari apa dan jam berapa, misalnya

\footnotetext{
${ }^{26}$ Marlian Hamedi. (Ka. Div Umum dan Personalia), Wawancara 03 Maret 2017
}

nasabah mau narik uang nah langsung hubungi/telp pihak bank. "27

Berdasarkan hasil wawancara dengan apa yang disampaikan oleh nasabah yang menabung pada funding celengan bahwa kita sudah punya kesepakatan sendiri dengan pihak bank kapan mau dijemput uangnya, mau hari apa dan jam berapa, misalnya kami mau narik uang maka langsung hubungi/telp pihak bank dan pihak bank langsung datang membawa uang dan slip penaikan ke warung kami.

e. Apakah semua nilai uang funding celengan yang akan ditabungkan oleh petugas Bank Safir atau bila tidak semua funding celengan ditabungkan, berapa nilai minimal yang ditabungkan untuk funding celengan tersebut?

"Tidak dibatasi, sesuai keinginan atau kehendak nasabah mau berapa menabung setiap harinya, belajar hemat, jujur, dan kepercayaan. ,28

Berdasarkan hasil wawancara yang disampaikan tersebut jadi menabung sesuai dengan keinginan nasabah misalkan mau menabung lima ribu rupiah setiap harinya, pihak Bank tetap akan menerimanya dan mengambilnya ketempat nasabah kemudian dimasukan kedalam buku tabungan.

\footnotetext{
${ }^{27}$ Nadiah. (Costumer Service), Wawancara 05 Maret 2017

${ }^{28}$ Syamsul Fajri Oktario. (Ka. Div. Funding Officer) Wawancara, 05 Maret 2017
} 
f. Apa alasan pemilihan tempat pemasaran funding celengan?

Berdasarkan hasil wawancara dengan karyawan Bank Safir Bengkulu didapati bahwa:

"Jadi setiap warung kita tawari dulu mau menabung atau tidak pada funding celengan, kita anggap pemilik warung semuanya banyak uang. Kalau kita punya referensi dekat rumah, tetangga dan lain-lain. ,29

Adapun alasan pemilihan tempat pemasaran funding celengan adalah merata pada semua warung yang ada dengan cara melakukan penawaran untuk produk funding celengan dengan cara mempromosikan produk funding celengan yang secara tidak langsung mempermudah nasabah untuk menabung dan tidak harus report datang ke Bank dan mengantri di teller, karena kita melayani dengan cara menjemput langsung kepada nasabah sehingga nasabah aman, dan tidak repot. Adapun daerah awal pelaksanaan funding celengan yaitu Kota Bengkulu, lamakelamaan mulai menyebar di daerahdaerah, daerah Penarik Muko-Muko, Manna, Ketahun, Kantor kas Rawa Makmur, Curup.

\footnotetext{
${ }^{29}$ Nadiah.(Costumer Service), Wawancara 06 Maret 2017
}

g. Apakah selama Funding celengan berjalan terjadi permasalahan?

“ Kalau terjadi permasalahan itu ada, tapi ada beberapa nasabah dia mau menabung tapi setiap penjemputan uangnya tidak bertambah malahan uangnya berkurang. Nah itu bisa kami pindahkan kewarung yang lain, tapi kalau lokasinya jauh dengan wilayah kami itu tidak kami jemput." 30

Jadi, dari penjelasan di atas dapat disimpulkan bahwa produk funding celengan ini dilakukan karena melatih agar belajar hemat, jujur, dan saling menjaga kepercayaan terhadap marketing dan nasabah.

h. Apa keunggulan yang dimiliki oleh produk funding celengan ini?

"Nasabah tidak repot-repot lagi harus datang ke Bank untuk menabung, petugas Bank datang langsung kewarungwarung untuk menjemput uangnya." 31

Jadi dari penjelasan diatas pihak nasabah tidak perlu datang langsung ke Bank karena petugas akan datang sendiri kewarung sesuai dengan perjanjian yaang telah disepakati antar kedua bela pihak misalkan mau hari apa uangnya mau diambil begitu juga dengan penarikannya.

\footnotetext{
${ }^{30}$ Marlian Hamedi, (Ka, Div Umum dan Personalia), Wawancara 08 Maret 2017

${ }^{31}$ Marlian Hamedi, (Ka, Div Umum dan Personalia), Wawancara 09 Maret 2017
} 
Adapun proses pelaksanaan diperoleh dalam menggunakan produk funding celengan di BPRS Safir Bengkulu funding celengan tersebut. "32 berdasarkan hasil wawancara dengan Jadi, dari penjelasan di atas dapat marketing Bank Safir yaitu: Kotak peneliti simpulkan bahwa produk funding celengannya dititipkan di warung nasabah celengan dilakukan karena melatih agar tapi kuncinya petugas Bank yang belajar hemat. Kejujuran adalah kunci megangnya, penjemputan uangnya oleh untuk percaya, ketika kita melakukan marketing itu sendiri tidak boleh sesuatu dengan kejujuran, kita memberikan diwakilkan pada orang lain. hati dan jiwa. Hal ini tidak hanya Adapun Faktor-faktor yang meningkatkan kualitas pekerjaan yang kita menyebabkan para pedagang warung lakukan, tetapi juga meningkatkan ikatan menabung pada funding celengan di BPRS yang kita meliki antara nasabah dan Safir Bengkulu yaitu "Pelayanannya, marketing dan orang-orang disekitar kita. faktornya menjaga kepercayaan antara Hal ini pun akan dirasakan oleh orang lain nasabah dan marketing. Jadi nasabah tidak yang mengenali kita, melihat kejujuran kita repat-repot lagi datang ke Bank untuk dan mulai memprcayai kita. Secara menabung, petugas Bank datang langsung bertahap dan seiring proses, mereka akan kewarung untuk menjemput uang yang mempercayai apa pun yang kita katakan akan ditabung pada funding celengan. atau lakukan adalah benar, tulus dan jujur.

\section{Faktor-faktor apa saja yang} menyebabkan para pedagang warung menabung pada funding celengan di BPRS Safir Bengkulu?

Berdasarkan hasil wawancara dengan apa yang disampaikan oleh nasabah yang menabungpada produk funding celengan. Mimi Asti, Etry, saibah, dan Bapak Tono sebagai nasabah yang menabung pada produk funding celengan.

"Produk funding celengan ini Hal ini dapat menjadi modal yang sangat penting bagi kita yang ingin melakukan usaha, karena kepercayaan adalah salah satu hal yang paling penting dalam menabungdan saling menjaga kepercayaan terhadap marketing dan nasabah. Pelayanan dalam produk ini, yaitu ramah, sopan santun terhadap nasabah, dan pelayanannya berbeda dengan bank lainnya karena bank ini menunjukkan sikap spiritual yang baik terhadap nasabah.

dilakukan supaya hasil tabungan tidak terduga, dan banyak keuntungan yang

\footnotetext{
${ }^{32}$ Mimi Asti. ( Nasabah Funding Celengan), Wawancara 03 Maret 2017
} 
Berdasarkan hasil wawancara funding celengan di dalam celengan dengan nasabah bahwa produk funding tersebut terdapat tiga bagian yaitu, celengan ini memberikan dampak positif tabungan warung, tabungan haji, dan bagi kami dalam artinya memberikan tabungan qurban. Akan tetapi celengan keuntungan.

"Tabungan tersebut setiap harinya tidak menentu hal itu tergantung dengan pendapatannya yang diperoleh atau omsetnya. Jika pendapatannya banyak makanya tabungannya juga banyak. Akan tetapi, jika pendapatanya menurun tabungannya juga akan menurun. Untuk tambahan modal tabungan ini per tahunnya diambil. Di warung ini hasil tabungannya dilakukan belum hampir 1 tahun. ,33

Pada saat mengajukan permohonan petugas Bank datang ke warung untuk menawarkan funding celengan. Mereka datang ke warung ini setiap harinya. Kesulitan yang diperoleh tidak ada melainkan justru lebih enak karena tidak terasa dalam setangah tahun pendapatanya sudah melampaui keinginan atau pendapatannya tidak menentu.

Tidak ada hambatan asalkan kita jujur dan jelas dengan kesibukkan nasabah dan tidak ada paksaan, pelayanan sangat baik, sopan, dan ramah-ramah, pokoknya enak banget.

Berdasarkan hasil wawancara dengan nasabah yang menabung pada

33 Bapak Tono. ( Nasabah Funding Celengan),Wawancara 03 Maret 2017 tersebut memiliki satu kunci untuk tiga bagian. $^{34}$

\section{B. Pembahasan}

\section{Pelaksanaan funding celengan di BPRS Safir Bengkulu}

Tabungan yang dibenarkan secara syariah, yaitu berdasarkan prinsip mudharabah dan wadhi'ah. Selain itu, Dewan Syariah Nasional (DSN) juga menetapkan ketentuan umum tabungan berdasarkan Wadhi'ah.

Hasil penelitian yang didapatkan oleh peneliti, yaitu di PT. BPRS Safir Bengkulu menerapkan bahwa tabungan Funding Celengan telah memenuhi syariat Islam dengan tidak adanya potongan prinsip mudharabah tetapi menggunakan akah Wadhi'ah, atau akad penitipan, dan bank tidak diperkenankan mengurangi nisbah keuntungan nasabah tanpa persetujuan yang bersangkutan sehingga memenuhi aturanaturan yang telah disyariatkan oleh bank. Dengan memberikan bonus tersebutdapatmenambah jumlah nominal tabungan serta membebaskan biaya administrasi untuk tabungan funding celengan. Karyawan bank melakukan

\footnotetext{
${ }^{34}$ Ibu Saibah. (Nasabah Funding Celengan), Wawancara 05 Maret 2017
} 
program dengan melakukan sosiolisasi dan

Dengan

memperhatikan mendatangi langsung kewarung-warung perkembangan BPRS Safir Bengkulu yang setiap hari sehingga nasabah tidak perlu datangke bank lagi. Dengan demikian, menabung lebih mudah dan tidak merepotkan nasabah. Hal ini sesuai dengan Syariat Islam yang telah ditentukan oleh Bank dan Dewan Syariah Nasional (DSN).

Hasil penelitian didapatkan bahwa dengan adanya kerja sama antara pihak bank dengan nasabah yang terus dilakukan akan menguntungan bagi nasabah dan marketing sehingga memudahkan nasabah dalam menabung. Dari kerja sama yang dilakukan oleh pihak bank dan nasabah,program yang dilakukan oleh bank dapat meningkatkan jumlah nasabah dengan melakukan promosi tentang produkproduk yang ada di Bank PT. BPRS Safir Bengkulu, bagi nasabah juga akan memperoleh kemudahan untuk melakukan peminjaman uang dengan bagi hasil yang tidak terlalu merugikan nasabah selaku pihak yang meminjamkan ke PT. BPRS Safir Bengkulu.

Pihak Bank juga berantusias dalam mengenalkan produk-produk yang ada di PT. BPRS Safir Bengkulu, serta melakukan penambahan petugas Funding celengan untuk menggabungkan segala efektifitas yang akan diterapkan di BPRS Safir Bengkulu dengan cara sosialisasi. demikian pesat dan dengan adanya otonomi daerah perbankan syariah turut serta dalam melakukan upaya pemberdayaan daerah, hal ini dilakukan dengan cara menghimpun dana dari daerah PT. BPRS Safir Bengkulu melakukan pemetaan terhadap daerahdaerah yang potensial.

c) Faktor-faktor apa saja yang menyebabkan para pedagang warung menabung pada funding celengan di BPRS Safir Bengkulu

Dari Hasil penelitian didapat pada umumnya masyarakat khususnya pedagang warung yang masih memiliki kebiasaan menabung dicelengan, hal ini menjadi peluang yang ditangkap oleh BPRS Safir Bengkulu untuk mengeluarkan produk funding celengan. Walaupun menabung dicelangan nasabah bisa memiliki buku tabungan dan kemudahan untuk menyetorkan uang dengan sistem dijemput. Proses menabung dilakukan dengan melibatkan pihak bank atau petugas funding celengan. Pihak bank datang langsung setiap harinya kewarung-warung sehingga nasabah yang akan menabung dapat melakukan penyetoran tabungan kepada petugas funding celengan dan menitipkan buku tabungan untuk dibawa dan diprint di PT. BPRS Safir Bengkulu sehingga lebih mudah dalam menabung. 
Menurut Dwi Septia Yolanda, Agustin, Eliza Julita, Sugianti, Siti Khadijah, menabung adalah hal yang bagus karena dengan menabung mengajarkan nasabah untuk tidak boros. Selain itu, juga dapat mengurangi pengeluaran untuk penentuan kebutuhan nasabah sehariharinya yang tidak terlalu penting karena nasabah terbiasa untuk menabung dibandingkan membelanjakan kelebihan uang padahal kebutuhan yang bersifat tersier.

Menurut Mimi Asti dan Etry dengan menabung di PT. BPRS Safir Bengkulu tidak perlu melakukan antrian di bank, karena petugas Bank datang langsung kewarung-warung untuk menjemput atau mengambil uang tabungan nasabah.

Alasan nasabah menabung lewat funding celengan karena letak geografis antara PT. BPRS Safir Bengkulu jauh. Dengan sistem adanya funding celengan PT. BPRS Safir Bengkulu berharap system syariah bisa menjangkau lebih luas masyarakat terutama yang tempat tinggal atau usahanya jauh dari BPRS Safir Bengkulu. Jadi pemasaran funding celengan ini biasanya digunakan dengan anak-anak kecil, sekarang produkfunding celengan ini dikelola oleh PT. BPRS Safir Bengkulu. sehingga pihak nasabah mudah dalam berkoordinasi dengan pihak PT. BPRS. Hal tersebut dianggap dapat melatih nasabah mengenal sistem syariah karena nasabah mayoritas beragama Islam dan juga nasabah dapat mengerti bahwa menabung tidak merugikan diri sendiri justru menguntungkan.

Bank Perkreditan Rakyat Syariah (BPRS) adalah lembaga keuangan bank yang dibawahi oleh dewan kebijakkan moneter, yang melakukan kegiatan ekonominya berdasarkan prinsip Islam atau syariah, tanpa menghalalkan adanya riba atau suku bunga yang berorientasi pada masyarakat di tingkat desa maupun kecamatan. Bank Perkreditan Rakyat Syariah (BPRS) didirikan berdasarkan UU No 7 tahun 1992 tentang perbankan Peraturan Pemerintah (PP) no.72 tahun 1992 tentang bank berdasrkan prinsipbagi hasil. Serta berdasarkan pada butir 4 pasal 1 UU. No 10 tahun 1998, pengganti UU no. 7 tahun 1992 tentang perbankan disebutkan bahwa Bank Perkreditan Rakyat Syariah (BPRS) adalah bank yang melaksanakan kegiatan usaha berdasarkan prinsip syariah, yang dalam kegiatannya tidak memberikan jasa lalu lintas pembayaran.

Bank Perkreditan Rakyat (BPR) yang melakukan kegiatan usaha berdasarkan prinsip syariah selanjutnya diatur menurut surat keputusan Direktur Bank Indonesia No. 32/36/KEP/DIR/1999. Tangal 12 Mei 1999 tentang Bank 
Perkreditan Rakyat berdasarkan prinsip Syariah.

\section{PENUTUP}

\section{Kesimpulan}

1. Pelaksanaan setelah adanya kesepakatan nasabah dengan pihak bank BPRS Safir maka pihak bank menitipkan kotak celengan dengan nasabah, nasabah menyimpan uangnya pada kotak tersebut. Setelah itu pihak bank mengambil uang tabungan Warung, tabungan Haji, dan tabungan Qurban, dan dicatat sesuai nominal tabungan.

2. Faktor-faktor yang menyebabkan para pedagang warung menabung pada funding celengan di BPRS Safir Bengkulu yaitu Pelayanannya yang ramah,menjaga kepercayaan nasabah, kemudahan dalam menabung, kemudahan mendapatkan informasi mengenai produk. Jadi nasabah tidak repat-repot lagi datang ke bank untuk menabung, karena petugas bank datang langsung kewarung untuk menjemut uang yang akan ditabung pada funding celengan.

\section{Saran}

1. Untuk memaksimalkan pelaksanaan funding celengan di BPRS Safir Bengkulu pihak Bank harus lebih giatuntuk mempromosikan atau mensosialisasikan kepada semua pihak terutama kepada pihak warung yang menjadi nasabah utama dari funding celengan ini.

2. Untuk terpenuhinya prinsip syariah di PT. BPRS Safir Bengkulu sebaiknya lebih memberi edukasi kepada semua pihak. Baik nasabah, maupun marketing, melalui workshop atau seminar mengenai produk funding celengan BPRS Safir Bengkulu.

\section{Daftar Pustaka}

Antonio, Muhammad Syafi'i.2001.Bank Syariah dari Teori ke Praktik. Jakarta: Gema Insani Press

Fatwa Dewan Syariah Nasional No.02/DSN-MUI/IV/2000.

Heykal, Muhamad Nurul Huda. 2010. Lembaga Keuangan Islam Tinjauan Teoritis dan Praktis. Jakarta: Kencana Prenada Media Group

Ismail, Perbankan Syariah, Jakarta: Kencana Prenada Media Group, 2011. Karim, Adiwarman A.2004. Bank Islam dan Analisis fiqih dan Keuangan, Jakarta: PT Rajagrafindo Persada, Kasmir. 2002.Dasar-Dasar Perbankan, Jakarta: PT Rajagrafindo Persada

Mirakhor, Zamir Iqbal Abbas. 2008. Pengantar Keuangan Islam Teori dan Praktek. Jakarta: Kencana Prenada Media Group 
Muhammad. 2004. Manajemen Dana Bank Syari'ah. Yogyakarta: Ekonesia

Yusuf, Muhammad, Junaedi. 2006. Pengantar Ilmu Ekonomi dan Perbankan Syariah, Jakarta: Ganeca Press

Nasution. 2003. Metodologi Research Penelitian Ilmiah.Jakarta: Bumi Aksara

PT BPRS Amanah Ummah, Laporan Tahunan 2012.

Tanjung, Hendri. 2012. Metodologi

Penelitian. Bogor: UIKA Press

Undang-Undang Republik Indonesia No. 21

Tahun 2008 tentang Perbankan Syariah

Sudarsono, Heri. 2003. Bank dan Lembaga

Keuangan Syariah. Ekonisia: Jakarta.

Muhammad. 2001. Sistem dan Prosedur

Operasional Bank Syariah. UII Perss:Yogyakarta

Kotler, Philip. 1995. Manajemen Pemasaran, Analisis, Perencanaan, Implementasi,dan Pengendalian. Terjemahan Buku I dan II. Salemba Empat: Jakarta.

Nabhan, Faqih. 2008.Dasar-dasar Akuntansi Bank Syariah. Lumbung Ilmu:Yogyakarta.

Soemitra, Andri. 2009. Bank dan lembaga

Keuangan Syariah, Kencana: Media Group.
Arif Al, Rianto Nur M, 2012. Dasar-dasar Pemasaran Bank Syariah, Bandung: Alfabeta.

Usman Nurdin , 2002. Konteks Implementasi Berbasis Kurikulum, (Jakarta:PT.Raja Grafindo persada).

H. Rusyaidi. Achmad , 2009. Pengadaan Tanah Untuk Kepentingan Umum: Antara Kepentingan Umum dan Perlindungan Hak Asasi Manusia. 